\title{
Evaluation of respiratory route as a viable portal of entry for Salmonella in poultry
}

This article was published in the following Dove Press journal:

Veterinary Medicine: Research and Reports

14 August 2014

Number of times this article has been viewed

\author{
Gopala Kallapura' \\ Xochitl Hernandez-Velasco ${ }^{2}$ \\ Neil R Pumford' \\ Lisa R Bielke' \\ Billy M Hargis' \\ Guillermo Tellez' \\ 'Department of Poultry Science, \\ University of Arkansas, Fayetteville, \\ AR, USA; ${ }^{2}$ College of Veterinary \\ Medicine and Animal Husbandry, \\ The National Autonomous University \\ of Mexico, Mexico
}

\begin{abstract}
With increasing reports of Salmonella infection, we are forced to question whether the fecal-oral route is the major route of infection and consider the possibility that airborne Salmonella infections might have a major unappreciated role. Today's large-scale poultry production, with densely stocked and enclosed production buildings, is often accompanied by very high concentrations of airborne microorganisms. Considering that the upper and lower respiratory lymphoid tissue requires up to 6 weeks to be fully developed, these immune structures seem to have a very minor role in preventing pathogen infection. In addition, the avian respiratory system in commercial poultry has anatomic and physiologic properties that present no challenge to the highly adapted Salmonella. The present review evaluates the hypothesis that transmission by the fecal-respiratory route may theoretically be a viable portal of entry for Salmonella in poultry. First, we update the current knowledge on generation of Salmonella bioaerosols, and the transport and fate of Salmonella at various stages of commercial poultry production. Further, emphasis is placed on survivability of Salmonella in these bioaerosols, as a means to assess the transport and subsequent risk of exposure and infection of poultry. Additionally, the main anatomic structures, physiologic functions, and immunologic defense in the avian respiratory system are discussed to understand the potential entry points inherent in each component that could potentially lead to infection and subsequent systemic infection of poultry by Salmonella. In this context, we also evaluate the role of the mucosal immune system as essentially one large interconnected network that shares information distally, since understanding of this sort of communication between mucosal sites is fundamental to establish the next phase of disease characterization, and perhaps immunization and vaccine development. Further characterization of the respiratory tract with regard to transmission of Salmonella under field conditions may be of critical importance in developing interventional strategies to reduce transmission of this important zoonotic pathogen in poultry.
\end{abstract}

Keywords: Salmonella, respiratory route, portal of entry, systemic dissemination

\section{Introduction}

There is good experimental and epidemiologic evidence that primary infection by Salmonella is through the fecal-oral route, along with an established requisite infectious dose. Previous published data have suggested that direct ingestion and contact are the most common routes of transmission for many zoonotic enteropathogens; however, inhalation of infectious particles should not be neglected. ${ }^{1,2}$ Airborne transmission of microbes is not restricted to agents causing respiratory disease, because enteric and other pathogens can also be transmitted by this route. The potential airborne transmission of zoonotic enteric pathogens, such as Salmonella, has not been well studied, even after repeated efforts, with reports suggesting that airborne transmission of Salmonella
Correspondence: Guillermo Tellez Department of Poultry Science, The Center of Excellence for Poultry Science, The John Kirkpatrick Skeeles Poultry Health Laboratory, I260 W Maple, POSC 0-I I 4, University of Arkansas, Fayetteville, AR 7270I, USA

Tel +l 4795758495

Fax + I 4795758490

Email gtellez@uark.edu 
is possible. ${ }^{3-5}$ Much of the uncertainty regarding airborne transmission and infection by Salmonella and other enteric pathogens has been associated with the relationship between bioaerosol particle size and number as well as the dose of pathogen it is carrying. ${ }^{6-8}$ Also, it is an established impression that bioaerosol generation and airborne transmission of a pathogen might be possible, but that infection eventually has to be fecal-oral, because settling of the microbe on feed and other surfaces will lead to infection through ingestion. ${ }^{5}$

The present review discusses the possibilities of airborne Salmonella infection pertaining to poultry, followed by discussion involving established poultry practices potentially leading to generation of Salmonella bioaerosols at every stage of commercial poultry production. Possible mechanisms of survival and transmission of Salmonella in bioaerosols gaining entry to the respiratory system in poultry are then discussed. Further, the role of avian respiratory anatomy, physiology, and immunology in airborne infection of Salmonella, making the respiratory route a viable portal of entry for Salmonella, is also discussed. A comprehensive understanding of the role of airborne transmission and subsequent infection of Salmonella in poultry may allow for more effective prophylactic strategies and interventions for this important economic issue in the poultry industry.

\section{Seriousness of the problem}

From the evolutionary point of view, bacteria of the genus Salmonella are some of the most remarkable and successful microorganisms, which are able to infect practically every living cell in the animal and vegetable kingdoms, and have extraordinary mechanisms to evade the immune system of plants, invertebrates, and vertebrates. Poultry is a major reservoir for food borne Salmonella enterica subspecies enterica serovars, with $S$. Typhimurium, $S$. Enteritidis, $S$. Heidelberg, $S$. Kentucky, and $S$. Senftenberg being the most prevalent serovars in US poultry. ${ }^{9,10}$ Nevertheless, these serovars are also linked to leading causes of food borne illness worldwide. ${ }^{11}$ In addition to the different disease outcomes, there is also a significant range of host specificity. In chickens, infection with host-specific Salmonella serovars $S$. Gallinarum and $S$. Pullorum cause septicemia, fowl typhoid, and Pullorum disease, respectively, ${ }^{12}$ whereas infections with non-host-specific serovars generally produce no clinical symptoms. In the last decade, significant progress has been made with regard to knowledge about Salmonella invasion and pathogenesis in mammalian hosts; however, information regarding Salmonella invasion and colonization mechanisms and interactions with host cells in poultry is limited and poorly defined. ${ }^{13}$ For most bacterial pathogens, virulence is a multifactorial process requiring two general classes of determinants. The first encompasses genes that participate in the physiological processes necessary for survival in host and non-host environments, and these genes are generally found in both pathogenic and nonpathogenic organisms. Salmonella infection has a complex pathogenesis. The pathogen is usually taken up by contaminated food. A variety of fimbrial adhesins are involved in initiation of contact with host cells. The first hallmark of bacterial-host cell interaction is invasion of nonphagocytic cells, eg, the epithelial cells of the intestinal mucosa. S. enterica is also a facultative intracellular pathogen that survives phagocytosis and is able to proliferate in infected host cells within a specific compartment, ie, the Salmonella-containing vacuole. ${ }^{14-16}$

Pathogenicity islands are genetic elements on the chromosomes of a large number of pathogens and are considered to be a "quantum leap" in the evolution of bacteria. ${ }^{17}$ However, the paradigm of pathogenicity islands is broken in some cases. $S$. Senftenberg, a serovar that is more resistant to environmental stresses, is frequently isolated from hatching houses and raw feed materials, and is adapted to colonize and persist in poultry houses for up to 2 years. ${ }^{18}$ The prevailing theory of Salmonella enteropathogenesis is that bacterial invasion of the intestinal epithelium is essential for virulence, and this requires the virulence-associated genomic region, Salmonella pathogenicity island 1 (SPI-1). ${ }^{17,19}$ However, $S$. enterica serovar Senftenberg strains isolated from food borne outbreaks have been reported to lack the invasionassociated locus SPI-1, indicating that SPI-1 is not essential for intestinal inflammatory disease. ${ }^{20}$ Yet, despite its lack of invasiveness, $S$. Senftenberg has emerged as a human pathogen, with the ability to acquire important pathogenic loci from other bacteria, such as the Yersinia high pathogenicity island, which encodes a yersiniabactin-mediated iron acquisition system present in highly pathogenic strains of Yersinia and several members of the Enterobacteriaceae family. ${ }^{21}$ Several studies have illustrated the presence of the high pathogenicity island in $S$. Senftenberg and the importance of poultry and pigs as a reservoir and vehicle for dissemination of zoonotic infection. ${ }^{22-25}$ Experimental and epidemiologic evidence suggests that primary Salmonella infection is by the fecal-oral route for poultry. Nevertheless, airborne transmission of Salmonella and similar enteric zoonotic pathogens has been historically neglected. Studies involving Salmonella bioaerosol production in combination with suggestions of vulnerable avian respiratory architecture indicate the respiratory route as a possible portal of entry for Salmonella in poultry. 


\section{Poultry practices and bioaerosol generation}

Control of Salmonella infection is vital at the apex of commercial poultry production, given that this organism can be transmitted vertically from hen to egg. ${ }^{26}$ Further, it is crucial to keep breeder production flocks free from Salmonella because a colonized flock will spread the bacteria to a large number of commercial flocks. Unlike production flocks, which are relatively short-lived, with a total lifespan of approximately 42 days, elite flocks, including breeders, may have a lifespan in excess of one year, so careful management is needed to ensure ongoing freedom from colonization by Salmonella and other pathogens. ${ }^{27}$

In this regard, hazard analysis and critical control pointbased intervention strategies have been developed and are used extensively. ${ }^{28}$ While many of these strategies have proven effective in laboratory or field trials, implementation in commercial operations has proven inconsistent in some cases, especially towards the lower end of the production pyramid. There have been consistent reports of Salmonella infection, with most hurdles beginning at the commercial hatcheries, followed by expansion of incidence to processing plants. ${ }^{29-31}$ With increasing reports of Salmonella infection, we are forced to question our present intervention strategies, which are established based on fecal-oral transmission as the major route of infection, and consider the possibility that airborne Salmonella might have a major unappreciated role.

\section{The hatchery}

Ideally, fertile eggs should be enteropathogen-free; however, this is not the commercial reality in many hatcheries. Dust and bioaerosols generated from contaminated eggs within a hatchery incubator, a critical control point, can spread enteropathogens to other areas of the hatchery depending on airflow. ${ }^{32}$ The presence of Salmonella in air samples from hatcheries is irrefutable and has been proven by various sampling and identification methods. ${ }^{32,33}$ Further, it is a general notion that dust carried by airflow settles elsewhere in the hatchery on uninfected eggs and hatched egg shells, and is then assumed to follow a typical fecal-oral route of transmission, with hatchlings pecking these contaminated egg shells. However, the possibility of entry and transmission of Salmonella through the respiratory route has historically received little attention. ${ }^{4,32,34,35}$

In modern poultry production, birds are held in the hatcheries for about 12-24 hours. Hatched birds experience prolonged high-density confinement in the hatchery, where they are exposed to circulating air that can carry Salmonella and other pathogens. Further, transportation of hatchlings from hatcheries to placement facilities adds additional confinement time, during which birds do not have access to feed and water. ${ }^{36}$ This early feed deprivation has been associated with delayed gut maturation ${ }^{37-39}$ and reduced immunity, ${ }^{40,41}$ increased susceptibility to pathogens, and a reduction in overall performance. ${ }^{42-44}$ Under such stressed conditions, the anatomic, physiologic, and immunologic state of hatchlings increases their vulnerability to infection. Considering these factors, it is reasonable to consider all possible routes of enteropathogen infection, especially the respiratory route, as a potential portal of entry for enteropathogens and Salmonella in context. Overall, we hypothesize that the hatchery environment is one of the most critical aspects of commercial poultry production with respect to airborne transmission of Salmonella, and hence various intervention strategies have to be developed at this stage to ensure prevention.

\section{Litter}

Prolonged use of litter with multiple sequential flocks of birds can harbor pathogens, ${ }^{45}$ and dust originating from litter due to air circulation and movement of birds may lead to generation of bioaerosols from the production system and infect chickens via the respiratory route. Today's large-scale poultry production, with densely stocked and enclosed production buildings, is often accompanied by very high concentrations of airborne microorganisms. ${ }^{1,46}$ In modern broiler houses with tunnel ventilation, large volumes of air are moved through the house to provide an optimal temperature and superior ventilation for growth of broilers. These large volumes of moving air may potentially contain a range of bacteria sourced from the internal environment of the house, including pathogens such as Salmonella. Hence, there is a possibility that circulation of air within the poultry housing environment provides opportunities for transfer of these pathogens throughout the production house and to the surrounding air environment. ${ }^{47}$ Several studies have reported the presence of high levels of airborne Escherichia coli, Salmonella, and Campylobacter inside poultry houses. ${ }^{29,31,48-53}$

\section{Transportation and processing}

The goal of on-farm pathogen reduction strategies is to deliver poultry to the processing plant with undetectable levels of Salmonella. However, fasting, catching, and transportation of poultry from primary production to processing can be significant in the dissemination of enteric pathogens, via contamination and subsequent cross-contamination because of stress and use of dirty crates, trucks, and catching/pickup crews. ${ }^{54}$ 
Controlling Salmonella contamination of poultry prior to slaughter may include limiting the exposure to bacteria in the final few hours before slaughter during on-farm loading, transportation, and holding at the processing plant. Understanding the kinetics of transmission of Salmonella to poultry from the environment during the last few hours before slaughter may identify a critical control point to reduce the number of contaminated birds entering the processing plants. If rapid airborne transmission by inhalation occurs immediately prior to slaughter, controlling dust and reducing transmission at this time point will be important. ${ }^{3,55}$ The first point of increased exposure prior to slaughter may occur when birds are taken off feed for 3-8 hours before loading. This can increase the flock's contact with Salmonella through increased ingestion of litter within the barn when in search of feed, ${ }^{56,57}$ which may eventually lead to fecal-oral transmission of infection. Withdrawal of feed is also associated with stress, somewhat similar to that of the hatchery conditions mentioned above. Second, disturbance of litter increases the amount of dust in the air, which may increase the risk of infection due to inhalation of Salmonella-contaminated particles or bioaerosols. ${ }^{3,56}$ Third, a large amount of dust is generated during the load-out process, and facilitates potential inhalation of Salmonella bioaerosols. Large fans blow air on turkeys to keep them cool during the summer months. From there, infection may spread through dust blown by fans to uninfected birds. These events occur in the last few hours before the birds are killed, and may increase exposure to Salmonella-laden dust. ${ }^{3,55}$ Pathogenic contamination of the respiratory tract in birds entering processing plants may contribute to carcass contamination, and Salmonella and Campylobacter have been detected in the respiratory tracts of broilers prior to entering the scald tank. ${ }^{58-62}$

\section{Survival of bacteria in bioaerosol}

The aerosolization process starts at three interfaces, ie, litter, dust, and air, during any production cycle. ${ }^{53}$ However, aerosolization and its transfer is a traumatic process for most microorganisms, and survival can be dependent on the mechanisms of aerosolization, the climate into which these organisms are launched, the distance they are travelling and, of course, the time involved in the whole process. ${ }^{62-64}$ Salmonella has been shown to be viable in laboratorygenerated bioaerosols for more than 2-4 hours. ${ }^{48,62}$ Continued survival of Salmonella in source material, such as dust or litter, and subsequent survivability in aerosols, can also depend on the serovar of Salmonella. S. Senftenberg could persist for more than 2 years despite cleaning, disinfection, desiccation, and depopulation, and was subsequently able to infect newly placed Salmonella-free layers. ${ }^{65}$ Humidity is known to play a major role in the survivability of Salmonella, ${ }^{33}$ but is one of the many factors that determine its survivability in bioaerosols. ${ }^{1,27,62}$

\section{Avian upper respiratory tract and bronchial airway}

Among the air-breathing vertebrates, the avian respiratory organ is considered to be the most structurally complex and the most functionally efficient gas exchanger. ${ }^{66-73}$ As a consequence, particles and particle-associated microorganisms are inhaled as unavoidable constituents of air flow. ${ }^{74}$ The architecture of the avian respiratory tract is an important component in terms of susceptibility and resistance to infectious agents. In this section, the main anatomic structure, physiologic functions, and immunologic defense mechanisms of the avian respiratory system are described to provide a general view of the conduit through which a pathogen has to travel.

\section{Upper respiratory tract}

The upper respiratory system begins at the nares and consists of passages that lead inhaled air and bioaerosol to the larynx. Physiologically, these oronasal structures function to heat and humidify inspired air, so can be expected to do the same to bioaerosols containing Salmonella, and indeed may provide favorable conditions for recovery and growth of Salmonella after traumatic transfer in bioaerosols.

Immune structures involved in the respiratory system of chickens and turkeys include Harderian glands, and conjunctivalassociated, paranasal, and nasal-associated lymphoid tissue. Though these structures are functionally important components of local immunity, especially in the upper respiratory tract. Local immunity of the respiratory mucosal system is ensured by nonspecific defensive reactions with an arsenal of mechanical and cellular defenses, supplemented when necessary by inflammatory and immune responses. ${ }^{75-77}$

There is no constitutive lymphoid tissue in the trachea. However, studies investigating infections of the respiratory system have shown reactivity of the tracheal mucosa to infections, despite a lack of essential lymphoid tissue. ${ }^{78}$ The tracheal mucosa is highly responsive to infection and reacts with extensive lymphocyte infiltration in the lamina propria and submucosa, followed by proliferation. However, according to some studies, immune responses within the trachea are age-dependent. ${ }^{77}$ The relationship between development of these immune structures and age is an important issue that 
requires further consideration for understanding of immune function related to the respiratory system. Conjunctivalassociated lymphoid tissue and nasal-associated lymphoid tissue, which are at the forefront of defense, are not fully functional germinal center and plasmatic cells at 4 weeks of age. $^{76,79}$ Further, B-cell responses were not detected in the trachea until 3 weeks post-infection in layer-type chickens, which is typically more than half the lifespan of the average broiler. Having assessed the high risk of contamination of chickens through the aerosol route in hatcheries, these structures appear to have a minute role in preventing infections acquired through inhalation. ${ }^{77}$

\section{Aerosols in the upper respiratory tract}

In conventional poultry production, birds are exposed to high loads of aerosolized particles, and considering the high probability of pathogens in these bioaerosols, the bird's upper respiratory tract would be very vulnerable to infection. The respiratory immune system has developed strategies to remove inhaled particles and to adequately respond to those microorganisms that cross the epithelial barrier in order to maintain integrity and function. Inhaled bioaerosol particles are eliminated from the respiratory system by multiple mechanisms, including aerodynamic filtration, mucociliary clearance, and phagocytosis, which are part of the innate defensive system in mucosal immunology. ${ }^{75,80-84}$ Inhaled foreign particles are initially removed by nasal mucociliary action via the mucociliary escalator mechanisms of the trachea, primary bronchi, and secondary bronchi. The primary bronchi and the roots of the secondary bronchi are lined mostly with columnar epithelial cells, which are longitudinally folded and ciliated. However, much of the remaining epithelium of the secondary bronchi is nonciliated, cuboidal, or squamous in structure; hence, mucociliary movement is restricted only up to the proximal end of the secondary bronchus. ${ }^{66,85}$ Thus, clearance mechanisms in the upper respiratory tract through the proximal end of the secondary bronchi primarily rely on particles becoming trapped in mucus, oral mucociliary transport, and expectoration or swallowing of trapped material. However, a detailed study by Hayter and Besch showed that particle size critically affects the site of deposition within the respiratory tract. ${ }^{86}$ This portion of the respiratory system forms the first line of defense against large inspired particles up to 4-7 $\mu \mathrm{m}$, but does not entrap many smaller particles. Cilia are smaller and fewer in the epithelium of the distal portion of secondary bronchi which raises uncertainty about the effectiveness of this site in preventing microorganisms in the air stream from entering the lower portions of the respiratory system. ${ }^{86}$

\section{Dose approximation for respiratory route}

Considerable evidence regarding generation and survivability of Salmonella within bioaerosols raises the question of exposure to infectious doses via respiratory inoculation. Assessment of exposure shows that the concentration of airborne microorganisms in the static air of animal farming environments can reach values of up to $10^{10}$ cells per cubic meter of air, ${ }^{87}$ and particulate matter having a size of $3 \mu \mathrm{m}$ can reach below the primary bronchi and may be involved in infection. Aerosols of about this size should be able to carry Salmonella, considering its typical diameter of around 0.7-1.5 $\mu \mathrm{m}$ and length of 2-4 $\mu \mathrm{m}$, and several studies have shown the impact of bioaerosols with regard to Salmonella infection in poultry. ${ }^{34,46,47,62,88,89}$

The impact of poultry house pollutants on particulate clearance from the respiratory system of birds remains largely unknown. Physical (dust), chemical (ammonia), and biological (bacteria or virus) conditions that reduce ciliary motility or disrupt the ciliated epithelium have been associated with increased risk of respiratory infection with several enteropathogens in poultry. ${ }^{64,85,90-95}$ There may not be a direct correlation between total respirable particles and their size and that of the Salmonella dose, and larger particles assumed to be removed by mucociliary clearance may also contribute to the dose involved through the respiratory route. Thus, particles that are not cleared by mucociliary mechanisms are exposed to the cellular and immunologic mechanisms of the bronchial airway.

\section{Immune system of the bronchial airway}

Most avian species, including chickens, lack draining lymph nodes but have a system of bronchial-associated lymphoid tissue (BALT) structures referred to as lymphoid nodules. ${ }^{79}$ In chickens, these structures are confined to the openings of most caudal secondary bronchi and also the mediodorsal, lateroventral, and laterodorsal secondary bronchi, while a wider distribution pattern including regions of longitudinal foldings of the mucosa has been observed in turkeys. ${ }^{79,96}$ Inspired air containing foreign materials bypasses the medioventral secondary bronchi opening, facilitating deposition of heavier foreign materials in the epithelium. It is not until after passing the filtering mechanism of the lungs and air sacs that air passes through the medioventral openings without BALT. ${ }^{97}$ 
Development of BALT depends on age and environmental stimulation. In day-old chickens and turkeys, no or very few infiltrating lymphocytes are seen in the primary bronchi region. ${ }^{98,99}$ Lymphoid nodules develop at these locations within the next 3-4 weeks, and cells producing immunoglobulin (Ig)M, IgG, or IgA can be detected; CD4+ and CD8+ T-cells are found at the same time localized in distinctive patterns..$^{77,79,80}$ Germinal centers can first be detected in 2-4-week-old birds. The numbers of cells producing IgG, IgA, or IgM continue to increase during the following weeks; however, it is now evident that BALT requires 6 weeks to develop fully in poultry, which approaches the age of the broilers at the end of a typical production cycle. . $6,78,80^{2}$

Mature BALT structures consist of lymphocyte aggregates that are covered by a distinct layer of epithelial cells known as follicle-associated epithelium, which harbors considerable numbers of lymphocytes. In 6-8 week-old birds, almost every bronchial opening was surrounded by a raised ring of lymphoid tissue and germinal centers are found in most lymphoi nodules, and occasionally plasma cells are seen under the follicle-associated epithelium. ${ }^{76,77}$

Epithelial cells in chicken BALT have been shown to lack microfold cells. However, recent research ${ }^{96}$ has described four epithelial cell types in the follicle-associated epithelium, depending on age, including cells which have irregular microvilli on their luminal surface and close contact with lymphocytes, and therefore are suggested to display some features of microfold cells. However, uptake of particles by these cells has not been observed, and characteristic organelles such as apical vesicles are absent. It has been suggested that these cells may not be involved in antigen uptake and processing, but participate in tissue repair. ${ }^{80}$ In a study that successfully reproduced fowl typhoid via intratracheal $S$. Gallinarum challenge, Basnet et al suggested that $S$. Gallinarum is likely to penetrate both microfold cells and epithelial cells on gastrointestinal lymphoid tissue and epithelial cells on BALT to infect lymphoid cells. ${ }^{100}$

The large numbers of heterophils found in the BALT of both chickens and turkeys may be functionally significant. Phagocytes, particularly heterophils, are an important element of avian respiratory defense systems because birds lack a large pulmonary macrophage population. Studies have suggested that macrophages and granulocytes are capable of transporting materials captured in the bronchial lumen to sites where specific immune responses may occur. ${ }^{79}$ Hence, to aid this process, at least two means of handling foreign particles in avian BALT are recognized, the first of which is passage between disrupted epithelial cells directly to phagocytic cells. On the other hand, follicle-associated epithelium cells are believed to mediate antigen contact with lymphocytes through endocytosis..$^{76,96,101}$

The appearance of a disrupted epithelial barrier over lymphoid nodules, supported by described endocytosis taking place in epithelial cells, might suggest that antigens would be readily available to lymphocytes and phagocytes in BALT. This demonstration of highly developed and constitutively present BALT structures in chickens and turkeys has encouraged some investigators to suggest that these mucosalassociated lymphoid structures may functionally compensate for the lack of lymph nodes in birds..$^{79,83,85,97}$ However, it remains to be shown if these structures specifically respond to antigenic stimulation by generation of memory $\mathrm{B}$ and $\mathrm{T}$ lymphocytes. The relationship between development of these immune structures and age is an important issue that needs attention. Having assessed the high risk of contamination of birds through the aerosol route in hatcheries, these immune structures seem to have a very minor role to play in preventing infections. Particulate matter and pathogens that cannot be efficiently cleared by the upper respiratory tract and bronchial airway may enter the parabronchial region or ventilating air sacs.

\section{Parabronchial region and avian air sacs}

Avian lungs have a highly intricate anastomotic joining of branches of tubular structures so as to make or become a continuous structure known as the parabronchial system. Hence, the functional unit of the avian lung is the parabronchus, in which terminal air spaces called air capillaries are heavily intertwined with blood capillaries for oxygen exchange. ${ }^{70} \mathrm{Air}$ capillaries and blood capillaries form approximately $90 \%$ of the exchange tissue. ${ }^{70,77,78}$ The air capillaries are generally strong due to a meshwork created between these and the blood capillaries, and mechanical compression of the lungs does not cause them to collapse. The lungs are ventilated unidirectionally and continuously in a caudocranial direction by the synchronized action of air sacs and parabronchial structures.

Air capillaries in poultry are much smaller in diameter (3-20 $\mu \mathrm{m}$ ) than the alveoli of mammals, and are estimated to be a fraction of the size of mammalian alveoli. ${ }^{102}$ This results in an increase in the surface area over which gas exchange occurs and aids in increasing the diffusing capacity of the lungs. It is important to note at this point that any particles or pathogens in aerosols passing beyond the secondary bronchi or the mucociliary escalator can potentially end up within 
the parabronchial region. Further, the parabronchi are lined by nonciliated cuboidal and squamous epithelium, so do not possess a means of moving inhaled foreign particles in the cranial/oral direction. ${ }^{102}$

\section{Blood-gas barrier}

The blood-gas barrier comprises endothelial cells that border blood capillaries, an intermediate extracellular matrix space called the interstitium, a single layer of air capillary epithelium. On average, the tissue thickness of the avian blood-gas barrier is known to be thinner than that in mammals, and various data show that this holds true even for weak flyers, such as domestic chickens. ${ }^{66,103-108}$

\section{Structural failure in the chicken lung}

During a respiratory cycle, avian lungs change in volume by a mere $1.4 \%{ }^{109}$ Based upon research on the microanatomy of avian lungs, it has been proposed that support of blood capillaries by surrounding air capillaries contributes to the strength of the capillary walls and thus allows a very thin and stable blood-gas barrier. ${ }^{67-69}$ However, these properties appear to have conflicting roles, because thinness is essential for efficient flux of oxygen by passive diffusion, and strength is crucial for maintaining structural integrity. ${ }^{72}$ Compared with mammals, arterial blood pressures in birds is much higher. Broilers and turkeys frequently experience problems with hypertension that lead to high myocardial stress, resulting in complications such as aortic aneurysm and ascites. ${ }^{67,68,109,110}$ Mechanical failure of the blood-gas barrier due to its thinness, is an important but overlooked factor. ${ }^{107,108}$ In addition, increases in pulmonary capillary blood pressure are probably the foremost direct challenge to the mechanical integrity of the blood capillary wall, especially the blood-gas barrier, and indirectly the epithelial-epithelial cell connections. Due to increases in pulmonary capillary blood pressure, avian lungs are more susceptible to mechanical pulmonary injuries and hence pathogenic diseases. Given these vulnerable conditions, the avian respiratory system would be expected to have a strong and robust immune system. However, the immune system in the avian lung is limited, especially during confinement of poultry under commercial conditions. Now we explore the reasons for and consequences of this limited immune system with respect to airborne Salmonella infection in poultry.

\section{Respiratory cellular defenses}

Phagocytes constitute the first line of defense against infectious agents in the respiratory system. Microscopic techniques have shown that macrophages are absent on the surface of air capillaries but present on the epithelial lining of the atria. ${ }^{70,111}$ Interestingly, macrophages were also seen in connective tissue below this epithelium on the floor of the atria ${ }^{112,113}$ and in the interatrial septa, ${ }^{80}$ indicating that phagocytic cells are strategically located at the start of the gas exchange area to clear the air of inhaled particles before it reaches the thin and vulnerable air capillaries. ${ }^{85}$ However, there have been reports of extremely low numbers of macrophages residing in the normal, steady-state respiratory tract of chickens, indicating that poultry lack resident phagocytes in the respiratory system to defend against invading infectious agents. ${ }^{82,114-116}$ Considering the importance of macrophage mediation of heterophil chemotaxis and activation, it is theorized that defense of the respiratory tract in poultry may be more susceptible to respiratory infections. ${ }^{75}$ Alveolar macrophages can easily be harvested by pulmonary lavage in mammals, but this technique is not successful in birds. ${ }^{111,115-122}$

\section{Avian air sacs}

Avian air sacs are thin and transparent membranous ventilating structures connected to the primary and secondary bronchi, and comprise most of the volume of the respiratory system. ${ }^{77,85,123,124}$ The two types of connections are direct when air sacs are coupled to the lungs by the primary bronchus and secondary bronchi, while indirect ones are formed entirely by the parabronchi. The caudal thoracic and abdominal air sacs, often collectively referred to as the caudal air sacs, arise from a second and third set of secondary (lateroventral and mediodorsal) bronchi and from continuation of the intrapulmonary primary bronchus.

The predominant sites of respiratory infection are the caudal air sacs, while cranial air sacs are the most devoid of infection, compared with other parts of the respiratory system. Part of the reason for this may be that the air sacs extend well beyond the limits of the coelomic cavity, with many bones being extensively pneumatized. ${ }^{125,126} \mathrm{~A}$ key explanation regarding the susceptibility of caudal air sacs to infection lies in the gas flow pathway and the mechanisms present in the parabronchi for particle removal. Due to the arrangement of the parabronchi, avian lungs have a flowthrough system of breathing, unlike the tidally ventilated mammalian respiratory system. Fresh inhaled air is mixed with residual stale air in the respiratory airways of the mammalian system, while inspired air completely bypasses the cranially lying openings of the medioventral secondary bronchi in avian systems, a process known as inspiratory aerodynamic valving. ${ }^{66,73,80}$ During the inspiratory phase, as 
well as in the expiratory phase, air flows into the mediodorsal and lateroventral secondary bronchi, and this flow pattern results in continuous ventilation of the parabronchial lung in a caudocranial direction. ${ }^{67,69-71,73,80}$ Due to this unidirectional flow, inhaled aerosol particles that could not be eliminated by several independent mechanisms, including aerodynamic filtration, mucociliary clearance, and phagocytosis in the upper respiratory tract end up in the caudal air sacs. ${ }^{86}$ These air sacs, because of their fragility, are very difficult to work with, so little is known about immunity within their structures. Granulocytes make up the majority of immune cells that can be detected in the air sacs, followed by macrophages, while lymphocytes are relatively rare. ${ }^{124}$ As in the lung parenchyma, mononuclear phagocytes have been detected in the connective tissue of the air sacs. ${ }^{112}$ Overall, the air sacs are deemed very vulnerable because of their location, their thin walls, and their low numbers of resident immune cells. All things considered so far, none of the anatomic, physiologic, or immunologic properties of the avian respiratory system give the impression of offering a major challenge to highly adapted Salmonella or any other pathogen invading the respiratory system. Taking into account the predisposing conditions in poultry production leading to bioaerosols of Salmonella and the inherent incongruity of the avian immune system, defenses may become overwhelmed and the avian respiratory system is likely to be susceptible to Salmonella infection via the respiratory route.

\section{Proposed Salmonella infection process via the avian respiratory route}

The perceived susceptibility of poultry to respiratory disease is proposed to stem from various human interventions, including extreme genetic manipulation and intensive management for maximum productivity. ${ }^{78,85}$ Since the domestication of the wild jungle fowl (Gallus gallus) in Southeast Asia, the domestic fowl has been selected for efficient weight gain and egg production through intense genetic breeding. Better husbandry and management may be partly responsible for the present performance of broilers, which reach a body mass of 2,500 $\mathrm{g}$ in less than 40 days when compared with the late 1940s when broilers took approximately 90 days to reach a slaughter body mass of $1,800 \mathrm{~g} .{ }^{127}$ Most of this progress is said to begin with an increased growth rate during the first 2 weeks post hatch. During such "directed, rather enforced, evolutionary selection" for maximal productivity, structural-functional disequilibrium is bound to occur and has been evident. ${ }^{70,75}$

The remarkable breeding progress in domestic birds is now sometimes associated with a mortality of up to $10 \%$ per flock because of various metabolic diseases. Depending on the etiological agent and specific defects in host defenses, a respiratory infection can be overwhelming and have severe consequences. In recent studies published by our laboratory, we have proposed that Salmonella, an established enteropathogen, can infect poultry via the respiratory route. ${ }^{128} \mathrm{We}$ evaluated this hypothesis using intratracheal administration of $S$. Enteritidis followed by enumeration of recovery of colony forming units (cfu) from the ceca-cecal tonsils and from the liver and spleen. $S$. Enteritidis challenged intratracheal colonized cecae to a similar or greater extent than oral administration at identical challenge levels. Chickens cultured for $\mathrm{cfu}$ enumeration from intratracheal-challenged chicks at same dose as orally challenged, resulted in an increase of $1.5 \mathrm{log}$ higher $S$. Enteritidis from ceca-cecal tonsils, and a much lower intratracheal dose of $S$. Enteritidis could colonize he ceca to the same extent as a higher oral challenge (Table 1). This trend of increased cecal colonization due to intratracheal challenge was observed in week-old birds, which are widely considered to be more difficult to infect via the oral route. Incidence data for the liver and spleen showed 33\%

Table I Evaluation of intratracheal infection of chickens with Salmonella Enteritidis*,**

\begin{tabular}{|c|c|c|c|c|c|c|}
\hline Group & $\begin{array}{l}\text { Dose cfu } \\
\text { of SE/chick }\end{array}$ & $\begin{array}{l}\text { Route of } \\
\text { challenge }\end{array}$ & $\begin{array}{l}\log _{10} \text { cfu of SE/g } \\
\text { of ceca content }\end{array}$ & $\begin{array}{l}\text { Ceca-cecal } \\
\text { tonsil }\end{array}$ & $\begin{array}{l}\text { Liver and } \\
\text { spleen }\end{array}$ & Trachea \\
\hline I & $1.5 \times 10^{4}$ & OR & $1.89 \pm 0.38^{c}$ & $5 / 12(4 I .66 \%)^{b}$ & $0 / 12(0 \%)^{d}$ & $\mathrm{I} / \mathrm{I} 2(8.33 \%)^{\mathrm{d}}$ \\
\hline 2 & & $\mathrm{IT}$ & $1.13 \pm 0.40^{c}$ & $8 / 12(66.66 \%)^{b}$ & $6 / 12(50 \%)^{b, c}$ & $8 / 12(66.66 \%)^{b, c}$ \\
\hline 3 & $2 \times 10^{6}$ & OR & $1.86 \pm 0.40^{c}$ & $8 / 12(66.66 \%)^{b}$ & $2 / / 2(16.66 \%)^{c, d}$ & $3 / 12(25 \%)^{d}$ \\
\hline 4 & & $\mathrm{IT}$ & $3.20 \pm 0.17^{b}$ & $12 / 12(100 \%)^{\mathrm{a}}$ & $10 / 12(83.33 \%)^{a, b}$ & $\mathrm{II} / \mathrm{I} 2(9 \mathrm{I} .66 \%)^{\mathrm{a}, \mathrm{b}}$ \\
\hline 5 & $1 \times 10^{8}$ & OR & $5.99 \pm 0.5 \mathrm{I}^{\mathrm{a}}$ & II/II (I00\%) & I/II (9.09\%) & $5 / \mathrm{II}(45.45 \%)^{\mathrm{c}, \mathrm{d}}$ \\
\hline 6 & & $\mathrm{IT}$ & $5.11 \pm 0.47^{\mathrm{a}}$ & $12 / 12(100 \%)^{a}$ & $1 \mathrm{I} / 12(91.66 \%)^{\mathrm{a}}$ & $12 / 12(100 \%)^{a}$ \\
\hline
\end{tabular}

Notes: *Chicks were challenged on day 7 with SE intratracheally or orally at concentrations of $1.5 \times 10^{4}, 2 \times 10^{6}$, or $1 \times 10^{8}$ cfu per chick, and 24 hours post challenge, the ceca-cecal tonsils were cultured to enumerate $\log _{10} \mathrm{SE} / \mathrm{g}$ of ceca content; the data are expressed as the mean \pm standard error of mean. Ceca-cecal tonsils, trachea, liver, and spleen enrichment data are expressed as positive/total chickens for each tissue sampled (\%). Adapted from Kallapura G, Morgan MJ, Pumford NR, et al. Evaluation of the respiratory route as a viable portal of entry form Salmonella in poultry via intratracheal challenge of Salmonella Enteritidis and Salmonella Typhimurium. Poult Sci. 20I4;93: $340-346 .{ }^{128}$ http://creativecommons.org/licenses/by/3.0/legalcode; ${ }^{\mathrm{a}-\mathrm{d}}$ The significant difference between groups is represented by different superscripts $(P<0.05)$, $\mathrm{n}=12 /$ group. Abbreviations: cfu, colony-forming units; SE, Salmonella Enteritidis; OR, orally; IT, intratracheally. 
of liver and spleen samples to be positive for $S$. Enteritidis administered intratracheally $\left(10^{6} \mathrm{cfu} /\right.$ chick $)$, as compared with $0 \%$ when administered orally (Table 1 ). These data suggest that the respiratory tract may be a largely overlooked portal of entry for Salmonella infections in chickens.

Current knowledge of Salmonella bioaerosol generation, its fate, transport, and survivability, as a means to assess the transport of bioaerosols and subsequent risk of exposure and infection of poultry was discussed previously. ${ }^{3,54,56}$ Further, analyses of poultry anatomy, physiology, and immunology have enabled an understanding of the inherent possibilities of Salmonella infection via the respiratory route. At this point, a meaningful understanding of how, where, and when the respiratory defenses are breached and the process of Salmonella infection and subsequent dissemination is essential, and is addressed in the following section.

\section{Salmonella survival in the upper respiratory tract}

Salmonella transiting through the respiratory tract does not face any of the hurdles faced when transiting through the gastrointestinal tract. Earlier we discussed the inefficacy of mucociliary clearance in the upper respiratory tract and the airway bronchial system, at least under poultry-rearing conditions, the consequences of which are multiple. Salmonella in bioaerosols can theoretically reach the parabronchial and caudal air sac regions, which are potentially the most vulnerable areas for infection. Due to the undeveloped immune lymphoid tissue in neonatal commercial poultry, and the impaired mucociliary clearance, the dose and age at which several Salmonella species infect birds has been found to be much lower than that required for oral infection. ${ }^{76,77,100,128}$

\section{Bacterial adhesion and invasion}

Adhesion of Salmonella to host epithelial cells in the gastrointestinal tract is the crucial step in infection and enables bacteria to colonize the host intestine, and this step is the result of coordination, in time and space, of expression of many virulence genes. As an enteric pathogen, the most formidable barrier that Salmonella has to overcome is the epithelial lining of the intestine. Several epithelial cell types are shown to be invaded by Salmonella, and Peyer's patches represent the main portal of entry in early Salmonella infection. ${ }^{129}$ The process of invasion and subsequent infection is widely accepted to be pathogen-driven, and host cells have a minor or no role to play, whereas in the respiratory system, age-related developmental differences in the nasal-associated lymphoid tissue and BALT structures may have functional consequences with respect to the pathogenesis of Salmonella. The disrupted epithelial barrier and previously described endocytosis could be a relatively easy portal of entry for Salmonella.$^{80}$ Thinning of the epithelium, reduced numbers of ciliated cells, and the absence of mucus-producing goblet cells facilitating a relatively open and localized interaction for Salmonella, which is known to infect its host through similar structures. In the parabronchial region, the scarcity of respiratory immune cells is clearly a potential advantage to Salmonella and any pathogen invading the respiratory system. Infiltration and subsequent phagocytosis of pathogens, to an extent greater than seen in mammals, might essentially be of advantage to Salmonella, which already has an established intracellular survival mechanism. ${ }^{14-16}$ It is interesting to note that a rapid change in virulence gene expression occurs during transition from the intestinal lumen into tissue that promotes systemic dissemination of Salmonella under enteric conditions. ${ }^{130}$ These rapid changes are considered to be due to various stimuli in the intestinal tract, such as bile and quorum sensing molecules. Because of these findings, one might suggest that transit of Salmonella through the respiratory airway, which essentially lacks these signals, might not result in expression of virulence genes, and any infection may be caused in spite of the host-driven mechanisms described above. Nevertheless, these suggestions require methodical evaluation and experimental evidence.

We recently conducted a series of field trials in North and South America to evaluate the association between cecal and tracheal recovery of Salmonella in chickens and turkeys from commercial flocks. Environmental humidity and temperature were measured to evaluate their effects on the frequency of positive isolations from the ceca and trachea. ${ }^{131}$ In all trials, Salmonella was recovered from tracheal samples more often than from cecal samples (Table 2). Environmental conditions were not associated with the incidence of recovery of Salmonella. These observations suggest that tracheal contamination can be a good indicator of Salmonella infection under commercial poultry conditions, and that tracheal samples can be used as a complementary tissue to the ceca and liver/spleen to increase recovery of Salmonella in infected poultry.

\section{Intracellular lifestyle and infection}

Salmonella must overcome the defense mechanisms of the enteric immune system through development of an intracellular lifestyle, ${ }^{132}$ which may also be true for infection through the respiratory route. Macrophages were seen in connective tissue below the parabronchial epithelium on the floor of the atria ${ }^{11-113}$ and in the interatrial septa,${ }^{80}$ indicating that 
Table 2 Evaluation of recovery of Salmonella in trachea, ceca, and liver/spleen in commercial chickens and turkeys*

\begin{tabular}{|c|c|c|c|c|c|c|c|}
\hline \multirow[t]{2}{*}{ Field trial and location } & \multirow[t]{2}{*}{$\begin{array}{l}\text { Bird } \\
\text { type }\end{array}$} & \multicolumn{2}{|c|}{$\begin{array}{l}\text { Average temperature } \\
\left({ }^{\circ} \mathrm{C}\right)\end{array}$} & \multirow[t]{2}{*}{$\begin{array}{l}\text { Average \% } \\
\text { humidity }\end{array}$} & \multicolumn{3}{|c|}{ Salmonella recovery/total (\%) } \\
\hline & & Minimum & Maximum & & Trachea & Ceca & Liver and spleen \\
\hline Trial I Bucaramanga, Colombia & Broiler & 18.9 & 25.3 & 82 & $96 / 1,061$ (9.0\%) & ND & ND \\
\hline Trial 2 Buenos Aires, Argentina & Broiler & 21 & 28 & 63 & $8 / 20(40 \%)$ & $0 / 20(0 \%)$ & $2 / 20(10 \%)$ \\
\hline Trial 3 Guanajuato, Mexico & Broiler & 18 & 28 & 65 & $28 / 100(28 \%)$ & $10 / 100(10 \%)$ & ND \\
\hline Trial 4 Arkansas, USA & Turkey & -2.9 & 4.9 & 67 & $34 / 100(34 \%)$ & $17 / 100(17 \%)$ & ND \\
\hline Trial 5 Arkansas, USA & Broiler & -2.7 & 7.7 & 69 & $3 / 150(2 \%)$ & $27 / 150(18 \%)$ & I I/I50 (7.3\%) \\
\hline
\end{tabular}

Note: *Adapted from Kallapura G, Botero A, Layton S, et al. Evaluation of recovery of Salmonella from trachea and ceca in commercial poultry. J Appl Poult Res. 20।4;23:I32|36. ${ }^{13 \mid}$

Abbreviation: ND, not determined.

phagocytic cells are strategically located at the start of the gas exchange area to clear the air of inhaled particles. ${ }^{85}$ Further, a study by Stearns et al showed that aerosolized inert iron particles with a diameter of $0.18 \mu \mathrm{m}$ were phagocytosed in the gas exchange area and endocytosed by epithelial cells lining the atria and the proximal parts of the infundibula, resulting in transport to tissue macrophages underneath the atrial epithelium. ${ }^{114}$ This suggests that, if Salmonella invasion occurs, these pathogens surely must adapt to an intracellular lifestyle, although this has not been described specifically.

Taking into consideration that Salmonella would not colonize respiratory tissue, it is necessary to recognize its subsequent fate, which unfortunately is unknown and needs elucidation. Under the conditions of the gastrointestinal tract, invasion by Salmonella causes a heavy influx of heterophils, a stereotypical yet effective response. Ironically, growth of Salmonella is aided by the inflammatory responses aimed at controlling luminal bacteria. Most of the intestinal microbiota is comprised of strictly anaerobic bacteria belonging to the Bacteroidetes and Clostridiales classes that rely on fermentation of amino acids and complex polysaccharides. One fermentation end product generated by the microbiota is hydrogen sulfide $\left(\mathrm{H}_{2} \mathrm{~S}\right)$, a cytotoxic compound that is converted to thiosulfate $\left(\mathrm{S}_{2} \mathrm{O}_{3}{ }^{2-}\right)$ by the colonic epithelium. During inflammation, neutrophils that transmigrate into the intestinal lumen release reactive oxygen species in an attempt to kill bacteria. A byproduct of releasing release reactive oxygen species is the oxidation of thiosulfate to tetrathionate $\left(\mathrm{S}_{4} \mathrm{O}_{6}{ }^{2-}\right)$. In contrast with fermenting microbiota, $S$. Typhimurium can use tetrathionate as a terminal electron acceptor to support its growth by anaerobic respiration, which is more efficient for energy production than fermentation. Also, anaerobic tetrathionate respiration facilitates growth on poorly fermentable carbon sources. All these examples imply that the respiratory environment is totally different from that of the gastrointestinal tract, and hence intrabronchial or intraparabronchial persistence is highly unlikely. ${ }^{133}$
Another mode via which Salmonella could potentially infect and spread systemically is by entering into blood directly and causing bacteremia. This mode is quite conceivable, considering the disrupted epithelial barrier of developing BALT structures, described endocytosis by epithelial cells. Conversely, continued survival of these bacteria entering the blood is thought to be unlikely. Recently, we evaluated and compared the infectivity of $S$. Senftenberg following oral gavage, intratracheal, or intravenous challenge in 7-day-old chicks with $S$. Senftenberg. This study was quite interesting in that it yielded new information regarding the ability of Salmonella to infect and colonize chickens. The ability of $S$. Senftenberg, a relatively noninvasive serotype, to rapidly colonize the ceca after intratracheal exposure was unexpected. It was remarkable to observe in those studies that intratracheal delivery of $S$. Senftenberg was the only route able to colonize the ceca of the chickens when compared with oral gavage or intravenous challenge in a dose-response fashion, suggesting that $S$. Senftenberg entering the blood is likely to be cleared and will not be able to colonize the ceca to the same extent as that seen with intratracheal challenge. ${ }^{134}$ Reports suggest that the blood-borne bacterial load is rapidly reduced from the circulation by trapping of bacteria in tissue macrophages, and the rate of reduction is significantly enhanced in the presence of opsonic factors in the blood. ${ }^{135}$ Further, passively immunized turkey poults, when challenged with $E$. coli, showed a rapid reduction in bacterial load by approximately $5 \log _{10}$ within 10 minutes post-intravenous challenge, in contrast with nonimmunized poults. ${ }^{136}$ Erythrocytes collected from lavaged chicken lungs readily phagocytosed $1.5 \mu \mathrm{m}$ diameter polystyrene particles, and $22 \%$ of chicken erythrocyte cells engulfed 1-6 particles after 5 hours of coincubation, compared with rat erythrocytes, which could not do the same. ${ }^{75}$ Although little is known about such interactions, the phagocytic activity of these chicken erythrocytes is attributed to nucleated properties. The role, if any, of these inherent phagocytic properties of erythrocytes in the defense of the pulmonary 
system and body in general requires further elucidation. As described above, it is currently thought that avian erythrocytes may clear particles from the lungs and deliver them to organs like the liver and spleen, where they may be destroyed or sequestered. Information regarding mucosal effector sites in avian lungs is also limited. The presence of intraepithelial and interstitial lymphocytes and isolation and functional characterization of CD8+ effector T-cells expressing interferon gamma from lung tissue of influenza virus-infected birds has been described. ${ }^{137,138}$

Unfortunately, these studies did not specify whether T-cells were obtained from the mucosal inducer or effector sides of lung tissue. Similarly, a recent study in an infectious bronchitis virus model in chickens applied microarray analysis to investigate the host response in the lungs but did not discriminate between BALT structures and the interstitial immune system as the source of RNA. ${ }^{139}$ With the chicken genome sequence now available, ${ }^{140}$ future work on hostpathogen interaction will increasingly apply this approach of more targeted gene expression analysis to lung tissue. ${ }^{141}$ Such work should take the distinct anatomic structures of the lung-associated immune system into account, which may very well show strikingly different phenotypic properties and functional activities.

\section{Systemic dissemination and cecal colonization}

Theoretically, Salmonella thriving and replicating in respiratory macrophages could be transported from the lungs to secondary lymphoid organs, such as the spleen, and spread systemically to the liver and potentially other organs. Systemic dissemination of Salmonella, after departing the respiratory organ, might well follow the same mechanisms observed for the fecal-oral route. Similar to the established process of oral infection, macrophages are major effector cells eliciting innate immunity, and also transport Salmonella to host tissues, ${ }^{142}$ primarily to organs of the reticuloendothelial system, such as the liver and spleen, along with kidney, blood, and reproductive tract. ${ }^{131}$ Macrophages provide a protected site for intracellular bacterial replication and further act as a vehicle of dissemination. Colonization of the gall bladder by Salmonella is of special importance, since this organ is recognized to be involved in the chronic carrier state. Eventually, Salmonella could end up in the intestinal tract via secretion of bile from the gall bladder, and begin its intestinal life cycle for further fecal dissemination.

Even though this may be the most conceivable mode of systemic spread of Salmonella, there could be other channels through which Salmonella could spread systemically. A growing body of evidence shows that the mucosa behaves as a systemwide network, suggesting that it should be seen from a holistic viewpoint as a global organ. Recent research evaluating the existence of communication between various mucosal sites indicates hitherto unappreciated levels of cross-talk between mucosal compartments, which influence mucosal immunity. ${ }^{143}$ Any substance that reduces ciliary motility or disrupts the ciliated epithelium could be expected to adversely affect the resistance of birds to microorganisms that normally enter via the respiratory system. Interestingly, an earlier study by Weinack et al, involving eight separate trials, considered this assumption and evaluated any effects of respiratory tract impairment on the gut microflora and gut pathogens, and reached an astounding conclusion. Chickens exposed to aerosolized Mycoplasma gallisepticum and infectious bronchitis virus started shedding higher doses of $S$. Typhimurium and E. coli more quickly than via oral challenge. ${ }^{90}$ The authors linked this observation to a decrease in intestinal microflora due to respiratory stress. However, they certainly suggested that the possibility of infection via aerosol inoculation for these organisms should not be ruled out.

Collectively, such studies indicate that the mucosal immune system is essentially one large interconnected network and that the individual components are very efficient at sharing information distally. When we extrapolate this concept in the context of the pathogenesis of Salmonella and hypothesize those macrophages, as a critical part of the immune system with regard to the migrating capabilities of Salmonella, it is possible that these macrophages can actually carry ingested Salmonella from the respiratory system to the cecal tissue. An experimental understanding of this sort of communication between mucosal sites is fundamental to the next phase of characterization of the disease, and perhaps vaccine development. One way in which we might provide evidence for such cross-talk is through use of molecular markers. Alveolar macrophages in mammalian systems are the most abundant antigenpresenting cells in the lungs, and play a critical role in regulating pulmonary immune responses to inhaled pathogens and allergens. Striking phenotypic differences between alveolar and peritoneal macrophages have been described, particularly with regard to CD11c expression. ${ }^{144}$ Identification of similar markers in the avian system would prove beneficial and might be employed to demonstrate the migration of respiratory macrophages from airway regions to cecal tissue. 


\section{Conclusion}

The present review has evaluated the hypothesis that transmission by the fecal-respiratory route may be a viable portal of entry for Salmonella in poultry. First, we have updated the current knowledge regarding Salmonella bioaerosol generation, and its transport and fate at various stages of commercial poultry production. Emphasis is placed on survivability of Salmonella in these bioaerosols as a means for assessing the transport and subsequent risk of exposure and infection of poultry. Additionally, the main anatomic structure, physiologic functioning, and immunologic defense of the avian respiratory system have been described to enable an understanding of the potential entry points inherent in each component that could potentially lead to infection and subsequent systemic infection of poultry by Salmonella. In theory, it is conceivable that, under field conditions, airborne Salmonella may be able to infect poultry by this route. Further clarification of the involvement of the respiratory tract in transmission of Salmonella under field conditions may be of critical importance in the development of interventions to reduce transmission of these pathogens in poultry. Understanding the communication between mucosal sites is fundamental to the next phase of disease characterization, and perhaps vaccine development. Further experiments using aerosol exposure are intriguing, because these could lead to insights important when developing live Salmonella vaccines, in addition to control of Salmonella on the farm.

\section{Disclosure}

The authors report no conflicts of interest in this work.

\section{References}

1. Dungan RS. Board-invited review. Fate and transport of bioaerosols associated with livestock operations and manures. J Anim Sci. 2010;88: 3693-3706.

2. López FE, de las Mercedes Pescaretti M, Morero R, Delgado MA. Salmonella typhimurium general virulence factors: a battle of David against Goliath? Food Res Int. 2012;45:842-851.

3. Harbaugh E, Trampel D, Wesley I, Hoff S, Griffith R, Hurd H. Rapid aerosol transmission of Salmonella among turkeys in a simulated holdingshed environment. Poult Sci. 2006;85:1693-1699.

4. Oliveira CJ, Carvalho LF, Garcia TB. Experimental airborne transmission of Salmonella Agona and Salmonella typhimurium in weaned pigs. Epidemiol Infect. 2006;134:199-209.

5. Wathes C, Zaidan W, Pearson G, Hinton M, Todd N. Aerosol infection of calves and mice with Salmonella typhimurium. Vet Rec. 1988;123: 590-594.

6. Hermann J, Muñoz-Zanzi C, Zimmerman J. A method to provide improved dose-response estimates for airborne pathogens in animals: an example using porcine reproductive and respiratory syndrome virus. Vet Microbiol. 2009; 133:297-302.

7. Douwes J, Thorne P, Pearce N, Heederik D. Bioaerosol health effects and exposure assessment: progress and prospects. Ann Occup Hyg. 2003;47: $187-200$.
8. Pillai SD, Ricke SC. Bioaerosols from municipal and animal wastes: background and contemporary issues. Can J Microbiol. 2002;48: 681-696.

9. Centers for Disease Control and Prevention. Salmonella surveillance. Annual summary. Atlanta, GA, USA: Centers for Disease Control and Prevention; 2006. Available from: http:/wwwnc.cdc.gov/eid/pdfs/ vol12no4_pdf-version.pdf. Accessed July 14, 2014.

10. US Food and Drug Administration. National Antimicrobial Resistance Monitoring System. Enteric bacteria. Executive report. Rockville, MD, USA: US Department of Health and Human Services; 2007. Available from http://www.fda.gov/downloads/AnimalVeterinary/SafetyHealth/ AntimicrobialResistance/NationalAntimicrobialResistanceMonitoringSystem/UCM209494.pdf. Accessed July 9, 2014

11. Scallan E, Hoekstra RM, Angulo FJ, et al. Foodborne illness acquired in the United States - major pathogens. Emerg Infect Dis. 2011;17: 7-15.

12. Barrow P, Neto OF. Pullorum disease and fowl typhoid - new thoughts on old diseases: a review. Avian Pathol. 2011;40:1-13.

13. He H, Genovese KJ, Swaggerty CL, Nisbet DJ, Kogut MH. A comparative study on invasion, survival, modulation of oxidative burst, and nitric oxide responses of macrophages (HD11), and systemic infection in chickens by prevalent poultry Salmonella serovars. Foodborne Pathog Dis. 2012;9:1104-1110.

14. Ohl ME, Miller SI. Salmonella: a model for bacterial pathogenesis. Annu Rev Med. 2001;52:259-274.

15. Okamura M, Lillehoj HS, Raybourne RB, et al. Differential responses of macrophages to Salmonella enterica serovars Enteritidis and typhimurium. Vet Immunol Immunopathol. 2005;107:327-335.

16. Setta A, Barrow PA, Kaiser P, Jones MA. Immune dynamics following infection of avian macrophages and epithelial cells with typhoidal and non-typhoidal Salmonella enterica serovars; bacterial invasion and persistence, nitric oxide and oxygen production, differential host

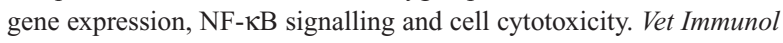
Immunopathol. 2012;146:212-224.

17. Ochman H, Groisman EA. Distribution of pathogenicity islands in Salmonella spp. Infect Immun. 1996;64:5410-5412.

18. Pedersen TB, Olsen JE, Bisgaard M. Persistence of Salmonella Senftenberg in poultry production environments and investigation of its resistance to desiccation. Avian Pathol. 2008;37:421-427.

19. Hensel M. Evolution of pathogenicity islands of Salmonella enterica. Int J Med Microbiol. 2004;294:95-102.

20. $\mathrm{Hu} \mathrm{Q}$, Coburn B, Deng W, et al. Salmonella enterica serovar Senftenberg human clinical isolates lacking SPI-1. J Clin Microbiol. 2008;46:1330-1336.

21. Petermann SR, Sherwood JS, Logue CM. The Yersinia high pathogenicity island is present in Salmonella enterica subspecies I isolated from turkeys. Microb Pathog. 2008;45:110-114.

22. Arnold T, Scholz H, Marg H, Rösler U, Hensel A. Impact of invAPCR and culture detection methods on occurrence and survival of Salmonella in the flesh, internal organs and lymphoid tissues of experimentally infected pigs. J Vet Med B Infect Dis Vet Public Health. 2004;51:459-463.

23. Carniel E. The Yersinia high-pathogenicity island: an iron-uptake island. Microbes Infect. 2001;3:561-569.

24. Ginocchio CC, Rahn K, Clarke R, Galan J. Naturally occurring deletions in the centisome 63 pathogenicity island of environmental isolates of Salmonella spp. Infect Immun. 1997;65:1267-1272.

25. Hacker J, Blum-Oehler G, Mühldorfer I, Tschäpe H. Pathogenicity islands of virulent bacteria: structure, function and impact on microbial evolution. Mol Microbiol. 1997;23:1089-1097.

26. Liljebjelke KA, Hofacre CL, Liu T, et al. Vertical and horizontal transmission of Salmonella within integrated broiler production system. Foodborne Pathog Dis. 2005;2:90-102.

27. Cox J, Pavic A. Advances in enteropathogen control in poultry production. J Appl Microbiol. 2010;108:745-755.

28. Jarquin R, Hanning I, Ahn S, Ricke SC. Development of rapid detection and genetic characterization of Salmonella in poultry breeder feeds. Sensors. 2009;9:5308-5323. 
29. Davies R, Wray C. An approach to reduction of Salmonella infection in broiler chicken flocks through intensive sampling and identification of cross-contamination hazards in commercial hatcheries. Int J Food Microbiol. 1994;24:147-160.

30. World Health Organization Microbiological Risk Assessment Series 2. Risk assessments of Salmonella in eggs and broiler chickens. World Health Organization Food and Agriculture Organization of the United Nations. Geneva, Switzerland: Food Safety Department, World Health Organization; 2002. Available from: http://www.fao.org/docrep/005/ y4392e/y4392e00.htm. Accessed June 17, 2014.

31. Byrd J, DeLoach J, Corrier D, Nisbet D, Stanker L. Evaluation of Salmonella serotype distributions from commercial broiler hatcheries and grower houses. Avian Dis. 1999;43:39-47.

32. Mitchell B, Buhr R, Berrang M, Bailey J, Cox N. Reducing airborne pathogens, dust and Salmonella transmission in experimental hatching cabinets using an electrostatic space charge system. Poult Sci. 2002;81:49-55.

33. Berrang M, Cox N, Bailey J. Measuring air-borne microbial contamination of broiler hatching cabinets. J Appl Poult Res. 1995;4:83-87.

34. Lever M, Williams A. Cross-infection of chicks by airborne transmission of Salmonella Enteritidis PT4. Lett Appl Microbiol. 1996;23: 347-349.

35. Wathes C, Howard K, Webster A. Survival of Escherichia coli in an aerosol at air temperatures of 15 and $30^{\circ} \mathrm{C}$ and a range of humidities J Hyg. 1986;97:489-496.

36. Choct M. Managing gut health through nutrition. Br Poult Sci. 2009;50: 9-15.

37. Yi G, Allee G, Knight C, Dibner J. Impact of glutamine and oasis hatchling supplement on growth performance, small intestinal morphology, and immune response of broilers vaccinated and challenged with Eimeria maxima. Poult Sci. 2005;84:283-293.

38. Uni Z, Smirnov A, Sklan D. Pre-and posthatch development of goblet cells in the broiler small intestine: effect of delayed access to feed. Poult Sci. 2003;82:320-327.

39. Noy Y, Geyra A, Sklan D. The effect of early feeding on growth and small intestinal development in the posthatch poult. Poult Sci. 2001;80:912-919.

40. Juul-Madsen HR, Su G, Sørensen P. Influence of early or late start of first feeding on growth and immune phenotype of broilers. Br Poult Sci. 2004;45:210-222.

41. Dibner J, Knight C, Kitchell M, Atwell C, Downs A, Ivey F. Early feeding and development of the immune system in neonatal poultry. J Appl Poult Res. 1998;7:425-436.

42. Henderson S, Vicente J, Pixley C, Hargis B, Tellez G. Effect of an early nutritional supplement on broiler performance. Int J Poult Sci. 2008;7: 211-214.

43. Hooshmand M. Effect of early feeding programs on broiler performance. Int J Poult Sci. 2006;5:1140-1143.

44. Halevy O, Geyra A, Barak M, Uni Z, Sklan D. Early posthatch starvation decreases satellite cell proliferation and skeletal muscle growth in chicks. J Nutr. 2000;130:858-864.

45. Vicente J, Higgins S, Hargis B, Tellez G. Effect of poultry guard litter amendment on horizontal transmission of Salmonella enteritidis in broiler chicks. Int J Poult Sci. 2007;6:314-317.

46. Fallschissel K, Kämpfer P, Jäckel U. Direct detection of Salmonella cells in the air of livestock stables by real-time PCR. Ann Occup Hyg. 2009;53:859-868.

47. Fallschissel K, Klug K, Kämpfer P, Jäckel U. Detection of airborne bacteria in a German turkey house by cultivation-based and molecular methods. Ann Occup Hyg. 2010;54:934-943.

48. Gast RK, Mitchell BW, Holt PS. Detection of airborne Salmonella enteritidis in the environment of experimentally infected laying hens by an electrostatic sampling device. Avian Dis. 2004;48:148-154.

49. Heber AJ, Peugh MW, Lutgring KR, Zimmerman NJ, Linton RH Poultry slaughtering plants: concentrations of microbial aerosols in poultry slaughtering and processing plants. ASHRAE Trans. 2006;1: 644-655.
50. Bull S, Allen V, Domingue G, et al. Sources of Campylobacter spp. colonizing housed broiler flocks during rearing. Appl Environ Microbiol. 2006;72:645-652.

51. Chinivasagam H, Tran T, Blackall P. Impact of the Australian litter re-use practice on Salmonella in the broiler farming environment. Food Res Int. 2012;45:891-896.

52. Kwon Y, Woodward C, Pillai S, et al. Litter and aerosol sampling of chicken houses for rapid detection of Salmonella typhimurium contamination using gene amplification. J Ind Microbiol Biotechnol. 2000;24: 379-382.

53. Chinivasagam H, Tran T, Maddock L, Gale A, Blackall P. Mechanically ventilated broiler sheds: a possible source of aerosolized Salmonella, Campylobacter, and Escherichia coli. Appl Environ Microbiol. 2009;75: 7417-7425.

54. Volkova VV, Bailey RH, Rybolt ML, et al. Inter-relationships of Salmonella status of flock and grow-out environment at sequential segments in broiler production and processing. Zoonoses Public Health. 2010;57:463-475.

55. Vieira-Pinto M, Tenreiro R, Martins C. Unveiling contamination sources and dissemination routes of Salmonella spp. in pigs at a Portuguese slaughterhouse through macrorestriction profiling by pulsed-field gel electrophoresis. Int J Food Microbiol. 2006;110:77-84.

56. Corrier D, Byrd J, Hargis B, et al. Presence of Salmonella in the crop and ceca of broiler chickens before and after preslaughter feed withdrawal. Poult Sci. 1999;78:45-49.

57. Ramirez G, Sarlin L, Caldwell D, et al. Effect of feed withdrawal on the incidence of Salmonella in the crops and ceca of market age broiler chickens. Poult Sci. 1997;76:654-656.

58. Berrang M, Meinersmann R, Buhr R, Reimer N, Philips R, Harrison M Presence of Campylobacter inthe respiratory tract of broiler carcasses before and after commercial scalding. Poult Sci. 2003;82:1995-1999.

59. Luber P. Cross-contamination versus undercooking of poultry meat or eggs which risks need to be managed first? Int J Food Microbiol. 2009;134:21-28.

60. Brynestad S, Braute L, Luber P, Bartelt E. Quantitative microbiological risk assessment of campylobacteriosis cases in the German population due to consumption of chicken prepared in homes. Int J Risk Assess Manag. 2008;8:194-213.

61. Adesiyun A, Offiah N, Seepersadsingh N, et al. Microbial health risk posed by table eggs in Trinidad. Epidemiol Infect. 2005;133: 1049-1056.

62. McDermid A, Lever M. Survival of Salmonella Enteritidis PT4 and Salm. typhimurium Swindon in aerosols. Lett Appl Microbiol. 1996;23: 107-109.

63. Donnison A, Ross C, Noonan M, Fisher G, Waller J. Bacterial survival and dispersal in spray irrigation aerosols. New Zealand Journal of Agricultural Research. 2004;47:575-585.

64. Brooks J, McLaughlin M, Scheffler B, Miles D. Microbial and antibiotic resistant constituents associated with biological aerosols and poultry litter within a commercial poultry house. Sci Total Environ. 2010;408:4770-4777.

65. Pedersen TB, Olsen JE, Bisgaard M. Persistence of Salmonella Senftenberg in poultry production environments and investigation of its resistance to desiccation. Avian Pathol. 2008;37:421-427.

66. Fedde M. Relationship of structure and function of the avian respiratory system to disease susceptibility. Poult Sci. 1998;77:1130-1138.

67. Watson RR, Fu Z, West JB. Morphometry of the extremely thin pulmonary blood-gas barrier in the chicken lung. Am J Physiol Lung Cell Mol Physiol. 2007;292:L769-L777.

68. Maina JN, Jimoh SA. Structural failures of the blood-gas barrier and the epithelial-epithelial cell connections in the different vascular regions of the lung of the domestic fowl, Gallus gallus variant domesticus, at rest and during exercise. Biol Open. 2013;2:267-276.

69. West JB, Fu Z, Deerinck TJ, Mackey MR, Obayashi JT, Ellisman MH Structure-function studies of blood and air capillaries in chicken lung using 3D electron microscopy. Respir Physiol Neurobiol. 2010;170: 202-209. 
70. Maina J. Some recent advances on the study and understanding of the functional design of the avian lung: morphological and morphometric perspectives. Biol Rev. 2002;77:97-152.

71. Watson RR, Fu Z, West JB. Minimal distensibility of pulmonary capillaries in avian lungs compared with mammalian lungs. Respir Physiol Neurobiol. 2008;160:208-214.

72. Maina JN, West JB. Thin and strong! The bioengineering dilemma in the structural and functional design of the blood-gas barrier. Physiol Rev. 2005;85:811-844.

73. Maina JN. Development, structure, and function of a novel respiratory organ, the lung-air sac system of birds: to go where no other vertebrate has gone. Biol Rev. 2006;81:545-579.

74. Mitchell B, Buhr R, Berrang M, Bailey J, Cox N. Reducing airborne pathogens, dust and Salmonella transmission in experimental hatching cabinets using an electrostatic space charge system. Poult Sci. 2002;81: 49-55.

75. Kiama S, Adekunle J, Maina J. Comparative in vitro study of interactions between particles and respiratory surface macrophages, erythrocytes, and epithelial cells of the chicken and the rat. JAnat. 2008;213: $452-463$.

76. Smialek M, Tykalowski B, Stenzel T, Koncicki A. Local immunity of the respiratory mucosal system in chickens and turkeys. Pol J Vet Sci. 2011;14:291-297.

77. de Geus ED, Rebel JM, Vervelde L. Induction of respiratory immune responses in the chicken: Implications for development of mucosal avian influenza virus vaccines. Vet $Q$. 2012;32:75-86.

78. Van Alstine WG, Arp LH. Histologic evaluation of lung and bronchusassociated lymphoid tissue in young turkeys infected with Bordetella avium. Am J Vet Res. 1988;49:835-839.

79. Bienenstock J, McDermott MR. Bronchus-and nasal-associated lymphoid tissues. Immunol Rev. 2005;206:22-31.

80. Reese S, Dalamani G, Kaspers B. The avian lung-associated immune system: a review. Vet Res. 2006;37:311-324.

81. King M. Mucus and its role in airway clearance and cytoprotection. In: Hamid Q, Shannon J, Martin J, et al, editors. Physiologic Basis of Respiratory Disease. Hamilton, ON, Canada: BC Decker Inc.; 2005.

82. Rose MC, Voynow JA. Respiratory tract mucin genes and mucin glycoproteins in health and disease. Physiol Rev. 2006;86:245-278.

83. Sato S, Kiyono H. The mucosal immune system of the respiratory tract. Curr Opin Virol. 2012;2:225-232.

84. Henning A, Schneider M, Bur M, Blank F, Gehr P, Lehr C-M. Embryonic chicken trachea as a new in vitro model for the investigation of mucociliary particle clearance in the airways. AAPS PharmSciTech. 2008;9:521-527.

85. Davison TF, Kaspers B, Schat KA. Avian Immunology. London, UK: Academic Press; 2008.

86. Hayter R, Besch E. Airborne-particle deposition in the respiratory tract of chickens. Poult Sci. 1974;53:1507-1511.

87. Radon K, Danuser B, Iversen M, et al. Air contaminants in different European farming environments. Ann Agric Environ Med. 2002;9: 41-48.

88. Harbaugh E, Trampel D, Wesley I, Hoff S, Griffith R, Hurd H. Rapid aerosol transmission of Salmonella among turkeys in a simulated holding-shed environment. Poult Sci. 2006;85:1693-1699.

89. Baskerville A, Humphrey T, Fitzgeorge R, et al. Airborne infection of laying hens with Salmonella Enteritidis phage type 4. Vet Rec. 1992;130: 395-398.

90. Weinack OM, Snoeyenbos G, Smyser C, Soerjadi-Liem A. Influence of Mycoplasma gallisepticum, infectious bronchitis, and cyclophosphamide on chickens protected by native intestinal microflora against Salmonella typhimurium or Escherichia coli. Avian Dis. 1984;28: 416-425.

91. Nagaraja KV, Emery DA, Jordan KA, Sivanandan V, Newman JA, Pomeroy BS. Effect of ammonia on the quantitative clearance of Escherichia coli from lungs, air sacs, and livers of turkeys aerosol vaccinated against Escherichia coli. Am J Vet Res. 1984;45:392-395.
92. Dwars RM, Matthijs MG, Daemen AJ, van Eck JH, Vervelde L, Landman WJ. Progression of lesions in the respiratory tract of broilers after single infection with Escherichia coli compared to superinfection with $E$. coli after infection with infectious bronchitis virus. Vet Immunol Immunopathol. 2009;127:65-76.

93. Popy N, Asaduzzaman M, Miah M, Siddika A, Sufian M, Hossain M. Pathological study on the upper respiratory tract infection of chickens and isolation, identification of causal bacteria. Bangl Vet. 2012;28: 60-69.

94. Whyte RT. Aerial pollutants and the health of poultry farmers. World's Poult Sci J. 1993;49:139-153.

95. Donham K, Blake J, Patterson P. Occupational health hazards and recommended exposure limits for workers in poultry buildings. In: Proceedings of the 2000 National Poultry Waste Management Symposium, Ocean City, MD, USA, October 16-18, 2000. National Poultry Waste Management Symposium Committee; 2000.

96. Fagerland JA, Arp LH. A morphologic study of bronchus-associated lymphoid tissue in turkeys. Am J Anat. 2005;189:24-34.

97. Haley PJ. Species differences in the structure and function of the immune system. Toxicology. 2003;188:49-71.

98. Fagerland JA, Arp LH. Distribution and quantitation of plasma cells, T lymphocyte subsets, and B lymphocytes in bronchus-associated lymphoid tissue of chickens: age-related differences. Reg Immunol. 1993;5:28-36.

99. Bienenstock J. Bronchus-associated lymphoid tissue and the source of immunoglobulin-containing cells in the mucosa. Environ Health Perspect. 1980;35:39-42.

100. Basnet H, Kwon HJ, Cho SH, et al. Reproduction of fowl typhoid by respiratory challenge with Salmonella Gallinarum. Avian Dis. 2008;52: 156-159.

101. Fagerland JA, Arp LH. Structure and development of bronchusassociated lymphoid tissue in conventionally reared broiler chickens. Avian Dis. 1993;37:10-18.

102. Lahellec C, Colin P, Bennejean G, Paquin J, Guillerm A, Debois J. Influence of resident Salmonella on contamination of broiler flocks. Poult Sci. 1986;65:2034-2039.

103. Watson RR, Fu Z, West JB. Morphometry of the extremely thin pulmonary blood-gas barrier in the chicken lung. Am J Physiol Lung Cell Mol Physiol. 2007;292:L769-L777.

104. Maina J, King A. The thickness of avian blood-gas barrier: qualitative and quantitative observations. J Anat. 1982;134:553-562.

105. West JB. Comparative physiology of the pulmonary blood-gas barrier: the unique avian solution. Am J Physiol Regul Integr Comp Physiol. 2009;297:R1625-R1634.

106. Marteyn B, West NP, Browning DF, et al. Modulation of Shigella virulence in response to available oxygen in vivo. Nature. 2010;465: 355-358.

107. West J, Mathieu-Costello O. Structure, strength, failure, and remodeling of the pulmonary blood-gas barrier. Ann Rev Physiol. 1999;61:543-572.

108. West JB, Mathieu-Costello O. Stress failure of pulmonary capillaries as a limiting factor for maximal exercise. Eur J Appl Physiol Occup Physiol. 1995;70:99-108.

109. West JB, Watson RR, Fu Z. The honeycomb-like structure of the bird lung allows a uniquely thin blood-gas barrier. Respir Physiol Neurobiol. 2006;152:115-118.

110. Lichtenberger M. Determination of indirect blood pressure in the companion bird. J Exotic Pet Med. 2005;14:149-152.

111. Maina JN, Cowley HM. Ultrastructural characterization of the pulmonary cellular defences in the lung of a bird, the rock dove, Columba livia. Proc R Soc Lond B. 1998;265:1567-1572.

112. Klika E, Scheuermann DW, Groodt-Lasseel D, Bazantova I, Switka A. Pulmonary macrophages in birds barn owl (Tyto tyto alba), domestic fowl (Gallus gallus f. domestica), quail (Coturnix coturnix), and pigeons (Columbia livia). Anat Rec. 1996;246:87-97.

113. Klika E, Scheuermann DW, Bazantova I, Switka A. Anchoring and support system of pulmonary gas-exchange tissue in four bird species. Acta Anat. 1997;159:30-41. 
114. Stearns RC, Barnas G, Walski M, Brain J. Deposition and phagocytosis of inhaled particles in the gas exchange region of the duck, Anas platyrhynchos. Respir Physiol. 1987;67:23-36.

115. Toth TE. Nonspecific cellular defense of the avian respiratory system: a review. Dev Comp Immunol. 2000;24:121-139.

116. Toth T, Siegel P, Veit H. Cellular defense of the avian respiratory system. Influx of phagocytes: elicitation versus activation. Avian Dis. 1987;31:861-867.

117. Nganpiep L, Maina J. Composite cellular defence stratagem in the avian respiratory system: functional morphology of the free (surface) macrophages and specialized pulmonary epithelia. J Anat. 2002;200: 499-516.

118. Toth TE, Curtiss III R, Veit H, Pyle R, Siegel P. Reaction of the avian respiratory system to intratracheally administered avirulent Salmonella typhimurium. Avian Dis. 1992;36:24-29.

119. Toth TE, Siegel PB. Cellular defense of the avian respiratory tract: paucity of free-residing macrophages in the normal chicken. Avian Dis. 1986;30:67-75.

120. Toth T, Veit H, Gross W, Siegel P. Cellular defense of the avian respiratory system: protection against Escherichia coli airsacculitis by Pasteurella multocida-activated respiratory phagocytes. Avian Dis. 1988;32:681-687.

121. Toth TE, Siegel P. Cellular defense of the avian respiratory system: dose-response relationship and duration of response in intratracheal stimulation of avian respiratory phagocytes by a Pasteurella multocida bacterin. Avian Dis. 1993;37:756-762.

122. Ficken MD, Edwards JF, Lay JC. Induction, collection, and partial characterization of induced respiratory macrophages of the turkey. Avian Dis. 1986;30:766-771

123. Farmer C. On the origin of avian air sacs. Respir Physiol Neurobiol. 2006;154:89-106.

124. Crespo R, Yamashiro S, Hunter DB. Development of the thoracic air sacs of turkeys with age and rearing conditions. Avian Dis. 1998;42: 35-44.

125. Bezuidenhout A. Light and electron microscopic study of the thoracic respiratory air sacs of the fowl. Anat Histol Embryol. 2005;34: 185-191.

126. Bezuidenhout AJ, Groenewald HB, Soley JT. An anatomical study of the respiratory air sacs in ostriches. Onderstepoort JVet Res. 1999;66: 317-325.

127. Aviagen Ltd. Broiler Management Manual ROSS 308. Scotland, UK: Aviagen Ltd; 2009.

128. Kallapura G, Morgan MJ, Pumford NR, et al. Evaluation of the respiratory route as a viable portal of entry form Salmonella in poultry vía intratracheal challenge of Salmonella Enteritidis and Salmonella typhimurium. Poult Sci. 2014;93:340-346.

129. Schauser K, Olsen JE, Larsson L-I. Immunocytochemical studies of Salmonella typhimurium invasion of porcine jejunal epithelial cells. J Med Microbiol. 2004;53:691-695.
130. Winter SE, Winter MG, Godinez I, et al. A rapid change in virulence gene expression during the transition from the intestinal lumen into tissue promotes systemic dissemination of Salmonella. PLoS Pathog. 2010;6:e1001060.

131. Kallapura G, Botero A, Layton S, et al. Evaluation of recovery of Salmonella from trachea and ceca in commercial poultry. J Appl Poult Res. 2014;23:132-136.

132. Toth TE, Curtiss R 3rd, Veit H, Pyle RH, Siegel PB. Reaction of the avian respiratory system to intratracheally administered avirulent Salmonella typhimurium. Avian Dis. 1992;36:24-29.

133. Winter SE, Thiennimitr P, Winter MG, et al. Gut inflammation provides a respiratory electron acceptor for Salmonella. Nature. 2010;467:426-429.

134. Kallapura G, Kogut MH, Morgan MJ, et al. Fate and dissemination of Salmonella Senftenberg post oral, intratracheal or intravenous challenge in broiler chickens. Avian Pathol. Epub 2014 May 13.

135. Qureshi MA, Heggen CL, Hussain I. Avian macrophage: effector functions in health and disease. Dev Comp Immunol. 2000;24: 103-119

136. Arp L. Effect of passive immunization on phagocytosis of blood-borne Escherichia coli in spleen and liver of turkeys. Am JVet Res. 1982;43: 1034-1040.

137. Seo SH, Peiris M, Webster RG. Protective cross-reactive cellular immunity to lethal A/Goose/Guangdong/1/96-like H5N1 influenza virus is correlated with the proportion of pulmonary CD8 T cells expressing gamma interferon. J Virol. 2002;76: 4886-4890.

138. Seo SH, Webster RG. Cross-reactive, cell-mediated immunity and protection of chickens from lethal H5N1 influenza virus infection in Hong Kong poultry markets. J Virol. 2001;75:2516-2525.

139. Dar A, Munir S, Vishwanathan S, et al. Transcriptional analysis of avian embryonic tissues following infection with avian infectious bronchitis virus. Virus Res. 2005;110:41-55.

140. Hillier LW, Miller W, Birney E, et al. Sequence and comparative analysis of the chicken genome provide unique perspectives on vertebrate evolution. Nature. 2004;432:695-716.

141. Rothwell L, Young JR, Zoorob R, et al. Cloning and characterization of chicken IL-10 and its role in the immune response to Eimeria maxima. J Immunol. 2004;173:2675-2682.

142. Vazquez-Torres A, Xu Y, Jones-Carson J, et al. Salmonella pathogenicity island 2-dependent evasion of the phagocyte NADPH oxidase. Science. 2000;287:1655-1658.

143. Gill N, Wlodarska M, Finlay BB. The future of mucosal immunology: studying an integrated system-wide organ. Nat Immunol. 2010;11: $558-560$.

144. Guth AM, Janssen WJ, Bosio CM, Crouch EC, Henson PM, Dow SW. Lung environment determines unique phenotype of alveolar macrophages. Am J Physiol Lung Cell Mol Physiol. 2009;296: L936-L946.
Veterinary Medicine: Research and Reports

\section{Publish your work in this journal}

Veterinary Medicine: Research and Reports is an international, peer-reviewed, open access journal publishing original research, case reports, editorials, reviews and commentaries on all areas of veterinary medicine. The manuscript management system is completely online and includes a very quick and fair peer-review system.

\section{Dovepress}

Visit http://www.dovepress.com/testimonials.php to read real quotes from published authors. 